\title{
'I'll sing you a song and a very pretty one': Broadsides, ballads and more
}

Here are catches, songs and glees/Some are twenty for a penny.

You shall have whatever you please/Take your choice for here are many.

Here is 'Nan of Glo'ster-Green'/Here's 'Lily of the Valley'

Here is 'Kate of Aberdeen'/Here is 'Sally in Our Alley'

Here is 'Mary's Dream' 'Poor Jack' / Here's 'The Tinker and the Tailor'

Here's 'Bow Wow' and 'Paddy Whack' /'Tally Ho' 'The Hardy Sailor'

Here's 'Dick Dook' 'The Heart Blade'/'Captain Wattle' and 'The Grinder'

And I've got 'The Country Maid'/Confound me though, if I can find her.

And 'Here's A Health to All Good Lasses'/Here's 'Come, Let Me Dance and Sing'

And what's better far than any finer/Here's 'God

Save Great George Our King',

'Hearts of Oak' and 'Rule Britannia.'

'The Ballad Singer' Fairburn's Universal Songster, 1825

ANY ATtemPt TO describe and analyse popular song from the period c.1770s to 1840 s faces a range of problems, from the conceptual (which songs should be considered popular?) to the evidential (how 'typical' are the songs that have survived?) and 
the interpretative (what meaning(s) did these songs have?), all of which make generalization a hazardous venture. ${ }^{1}$ Further, while there are various glimpses into the world of popular song, much, particularly performance and audience response, remains unknown, which makes all the more important the 'hard leap of historical understanding [required] to think our way out of modern notions of the place of song in society into a very different situation.' ${ }^{2}$ The purpose of this chapter is to consider the range of material, from ballads and broadsides, to chapbook and songsters, as background to the following two chapters which will consider the content of different types of songs and the insights they provide.

Although the precise contours are often unclear, singing was a common-place part of daily life. People sang at work, at the plough tail and at the loom, and there were even work songs. People sang at leisure. They sang privately, maybe solitarily, and they sang collectively. They sang in informal settings, not least the local inn or beerhouse, but they also sang in formal settings, some secular, others sacred; and in doing so, they drew from a variety of sources and traditions. But what did they sing? The question can be answered with some confidence in the case of the chapel choir or the choral society but much less so when talking about the ale-house sing-song. Little is known about the repertoires of ordinary men and women. John Clare's father, Parker Clare, allegedly knew more than a hundred songs, which he sang or recited. ${ }^{3}$ It is impossible to say how unusual he was, assuming the claim to be correct. Exceptionally, the Copper family of Rottingdean had a repertoire of songs passed down the generations, but more typically, Isaac Bawcombe, a young shepherd at the turn of the nineteenth century, sang 'old songs and ballads he had learnt in his young years - 'Down in the Village,' The Days of Queen Elizabeth,' 'The Blacksmith', 'The Gown of Green,' 'The Dawning of the Day' and many others.' It is likely that many people had a small range of songs, including one or two 'party pieces' to be sung at special occasions as well as other, well-known pieces to be sung collectively and informally. ${ }^{5}$ But how many people were like Clare's friend, Gregory? He was 'fond of amusement and a singer tho his notes was not more varied than that of the cuckoo as he had but 2 Songs one called 'the milking pail' and the other 'Jack with his broom."' 
There were a small number of known local musicians of sufficient skill to be called upon to sing and play at various events; and a smaller number, who were semi-professional or professional, making their living in the streets of towns and cities, at fairs and feasts, often tramping the country in search of an opportunity to make money. Mayhew captured the variety and insecurity of such a lifestyle. When 'the fairs are frequent and the river steamers with their bands of music run off and regularly and outdoor music may be played until late, the calling of the street musician is 'at its best." But during wintertime he was "frequently starving, especially if he be what is called 'a chance hand' and have not the privilege of playing in public-houses when the weather renders it impossible to collect a street audience. ${ }^{7}$ His respondents also provide an insight into the mix of music from which they made a living. Sensationalism was a prominent feature. 'There's nothing beats stunning murder, after all,' one running patterer boasted. 'There was Rush - I lived off him for a month or more. ${ }^{8}$ But more run-of-the-mill murders made for good copy, such as the 'Horrid and Inhuman Murder, Committed by T. Drory on the Body of Jael Denny at Donninghurst, a Village in Essex.' Using extracts lifted from a newspaper 'we worked it every way ... We had half sheets, and copies of werses. A werry tidy book' he said with evident pride. ${ }^{9}$ Another, female interviewee started as a glee singer with two others, performing in streets and squares and occasionally in tap-rooms. ${ }^{10}$ "We used to sing "Red Cross Knight," "Hail Smiling Morn," and harmonize "The Wolf." 11 Popular songs of the day - 'Alice Gray,' 'The Tartar Drum' and 'The Mistletoe Bough' - were taken from the local concert-rooms and sung on the streets. However, 'the very best sentimental song that ever I had in my life, and which lasted me off and on for two years, was Bayley's "Isle of Beauty." I could get a meal quicker with that than any other.'

\section{Ballads and the 'oral tradition'}

The English are prone to mythologizing the countryside and its inhabitants. Reassuring visual images of an ordered landscape with a contented workforce are reinforced by a written arcadian imagery in which milkmaids and shepherdesses sing happily at work while the 'merry plough-boy ... whistle[s] 
o'er the lea." ${ }^{12}$ Within this rural myth exists a more specific but equally misleading notion - that of a distinct popular oral tradition, rooted in the (often indeterminate) middle ages, which was corrupted and destroyed by the new commercial print culture, which culminated in the song-writing industry of the Victorian music hall. This view can be traced back through the folksong collectors of the late-nineteenth century, to Sir Walter Scott and Thomas Percy, whose Reliques of Ancient English Poetry (first published in 1765) referred to 'old ballads' as the 'select remains of our ancient English bards and minstrels. ${ }^{13}$ Nowhere was this aesthetic judgement clearer than in the work of the highly influential ballad scholar, Francis Child, for whom orally-transmitted ballads, 'the true popular ballads, the spontaneous products of nature,' were far superior to the 'vulgar' printed ballads. ${ }^{14}$ The clash between oral and print ballads was thus confirmed as a cultural conflict. Printed ballads, in Child's view, 'are products of a low kind of art ... thoroughly despicable and worthless. ${ }^{15}$ However, this idea of a distinct oral tradition was flawed from the outset. Child was not alone in being dependent on printed texts to complete certain ballads. ${ }^{16}$ In contrast, in present thinking the old distinctions between oral and printed are less contentious, with the emphasis on 'cross-fertilization' and 'hybrid products', which highlight the complex but productive interaction between printed, commercial songs and the older, oral tradition. ${ }^{17}$

There was a corpus of songs, which could be traced back through the centuries. Certain songs, such as 'Barbara Allen,' 'John Barleycorn' and even 'Three Blind Mice' had a long pedigree, though few (if any) can be confidently dated back beyond the sixteenth century. There were also long-standing 'heroic' ballads, most notably the celebration of the battle of Otterburn, 'Chevy Chase,' and other folkloric stories, such as 'The False Bride,' 'The Cruel Mother' and 'Broomfield Hill,' though they were relatively few in number. ${ }^{18}$ Nor was there any obvious pattern to these songs. 'Give Us Once a Drink' was a straight-forward drinking song (better known later as 'The Barley Mow') and 'Martin Said to his Man' celebrated drinkinduced nonsense; 'Noble Fox Hunting' was a sporting song, 'Come Write Me Down' a celebration of love and 'Don't Let Me Die an Old Maid' a self-explanatory lament.The resilience 
of these songs is striking and contradict claims of a 'mass extinction of old ballads' from the late-eighteenth century onwards. ${ }^{19}$ Undoubtedly, some ballads, such as 'The Suffolk Miracle,' disappeared and others, such as 'The Knight and the Shepherd's Daughter' declined in popularity, but this was not the whole story. The time-honoured 'Chevy Chase,' according to Joseph Addison, 'the favourite ballad of the common people of England' in the early eighteenth century, evolved over time. ${ }^{20}$ Later versions, such as that printed in Percy's Reliques, were significantly tidied-up versions of earlier 'minstrel' versions, highlighting how such songs were themselves part of a wider, commercially oriented, popular song market. ${ }^{21}$ Similarly, tunes, such as 'Off She Goes' or 'We Won't Go Home Till Morning,' were recycled with new words. Some fifty songs, including execution ballads and other moralising songs, have been directly linked to the tune 'Aim Not Too Low' (or 'Fortune My Foe') while the better-known, 'Lillibulero' was similarly much used. ${ }^{22}$ The very familiarity of the tune contributed - or so it was hoped - to the success of the song in a market that extended beyond the educated elite. The Diceys, William and Cluer, printed 'ancient ballads' in chapbooks and broadsides for a popular market. ${ }^{23}$ John Clare's song collection included variants of Dicey broadside texts, even though by the second quarter of the nineteenth century such "old ballads" were beginning to sound distinctly dated. ${ }^{24}$

\section{Collections and chapbooks}

As with dance tunes, there was an intermingling of popular and elite culture. Thomas D'Urfy's Wit and Mirth, or Pills to Purge Melancholy, which ran to six volumes and over a thousand songs by the early eighteenth century, was an important source of popular songs and tunes. ${ }^{25}$ D'Urfey moved in court circles, working with composers such as Henry Purcell and John Blow, which was partly reflected in his collection. Other songs, such as 'A Shepherd Kept Sheep On A Hill So High' he composed, but he also brought together material from a wide range of sources, including theatre songs, many of which already existed in broadside form, drolleries, such as Sportive Wit (1656) and Merry Drollery (1661) and folio song-books, such as Banquet of Music (1688-92) and Thesaurus Musicus (1693-6). ${ }^{26}$ At times his debt 
to others was considerable. Thirty-three of the fifty-seven songs in volume five were taken from Choice Ayres \& Songs (1684). Other songs were established favourites - 'Joan's Ale' and 'Yonder Comes a Courteous Knight;' others celebrated triumphs of the day - 'Sing Mighty Marlborough's Story;' and others were bawdy - 'There Was an Old Woman Liv'd under a Hill' and especially 'As Oyster Nan Stood by Her Tub' which appeared in a section entitled Pleasant and Divertive. ${ }^{27}$ D'Urfey's volumes were not intended for a mass market. The first two volumes sold at $1 \mathrm{~s} 6 \mathrm{~d}$ (7.5p but the equivalent of $\mathcal{f} 11$ at present prices), while volume three could be purchased in three $6 \mathrm{~d}$ instalments, or as a bound copy for $2 \mathrm{~s}\left(10 \mathrm{p}\right.$ or the equivalent of $\mathcal{E}^{14.50)} .^{\star}$ But, if few people purchased Pills to Purge Melancholy, it provided a valuable resource for professional and semi-professional singers, whose performances helped to disseminate these songs to a wider (and originally unintended) audience.

Technological improvements in papermaking and printing facilitated production on a larger scale and at cheaper prices. Chapbooks, small booklets of folded paper without binding or covers, became more common from the late eighteenth century onwards. Many were titled simply 'Garlands' and were little more than a collection of unrelated songs popular at the time, which sold for $6 \mathrm{~d}$. (2.5p or about $f^{3}$ at current prices). Value for money was not guaranteed as the content could vary considerable in both quantitative and qualitative terms. Songs were often plundered from other sources and co-existed with broadside versions. Nonetheless, they were a welcome addition. The publisher William Tinsley recalled the popularity of the visits of the chapbook sellers to South Mimms (Hertfordshire) in the late 1830s and 1840s and their sales to the unschooled farm labourers of the village. ${ }^{28}$

London was an important centre of production but so too were certain provincial cities, notably Newcastle. ${ }^{29}$ Chapbook production started here around the 1770 s and continued until the 1860 s, peaking in the first three decades of the nineteenth

The weekly wage of an agricultural labourer in the late eighteenth century could be as low as 6 s a week, making the bound version of volume three the equivalent of a quarter of the weekly wage. Looked at another way, at 2018 prices the same volume would cost c. 12.50 . See measuringworth.com for a discussion of the methodology involved. 
century. The trade was in the hand of ten or a dozen printers, including two family firms, Angus and Fordyce and the prolific John Marshall. Between the mid-1770s and the mid-1860s, the city's chapbook printers produced just under 400 chapbooks, containing 1860 songs, as well as a further 1000 broadside songs. 'Barbara Allan' and 'Froggie Went A-Courtin" where to be found alongside 'The Lass of Richmond Hill' and 'The Last Rose of Summer.' There were also a significant number of local songs, such as 'The Toon Improvement Bill' and 'The Quayside Shaver.' Once again, diversity was the order of the day. Other songs included 'John Anderson, My Jo, 'Auld Lang Syne,'The Greenwich Pensioner' (written by Charles Dibdin), Henry Carey's sentimental 'Sally in our Alley' and, reflecting a craze of the day, 'Jim Crow from Kentucky' and 'Jim Crow's Visit to Newcastle.' As the chapbook trade started to decline, broadsides and songsters became more important and not just in the north-east. In the longer run, the chapbook was to disappear, squeezed out by the songsters of the mid-nineteenth century, but for half a century or more such song collections provided a conduit between the theatres and pleasure gardens and a wider audience.

\section{Broadside ballads and songsters}

Far more common and influential was the broadside ballad, which existed in a complex nation-wide system of production and distribution. Much discussion of publication has focussed on the 70 or so London-based printing firms - of whom James Pitt and James Catnach are the best known - but there were printers to be found across the country, notably in Newcastle and Birmingham, but also in smaller towns, such as the Merry family in Bedford, Thomas Porter in Highworth, near Swindon, and Robert Walker in Norwich, and in more rural settings in Hampshire and Wiltshire, as well as (occasionally) in remoter counties such as Devon and Cornwall. ${ }^{31}$

In the early nineteenth century a single broadside song cost $1 / 2 \mathrm{~d}$, (c.25p in current prices) a broadside containing two or three songs $1 \mathrm{~d}$. Broadside ballads reached a wider audience that went well beyond simple sales figures. They were pasted on cottages walls, as well as in beer houses and inns; pinned on looms, as well as being passed from hand to hand, deliberately or 
by accident; and their words learned by heart from the patterers, who sang them in the streets, at the fairs and wherever there was an audience. John Clare had little time for 'the ballad singers [who] rant and rave' but recognized their success in persuading 'hodge [the farm labourer] whose pockets wont stand treats more high' to part with his penny and wistfully noted that the 'ballad in the ploughman's pocket [brought] a greater fame than poets ever knew.'32

Broadside ballads were ephemeral, surviving haphazardly through a combination of chance and the whims of later antiquarian collectors. Again, they contained songs from an older, oral tradition alongside newer, theatre songs as well as songs from largely unknown street authors, broadside hacks, among whom only John Morgan and George Brown have entered the historical record. ${ }^{33}$ Eighteenth-century broadside ballads generally contained only the words of the song, though it was common practice to suggest a tune. The fortunes of the broadside ballad fluctuated over time. For much of the eighteenth century they were rude in health (and often rude in content), but they came under attack in the 1790s and 1800s as the result of longer-term changes in morality and manners and short-term panics created by the war with France. Those, like magistrate and police reform advocate, Patrick Colquhoun, afeared of the French and dangerous radical ideas, demanded 'loyal' songs. Those, like Hannah More, affronted by ribaldry and fearful of immorality looked to uplifting literature. The success of such campaigns from above were limited. More's Cheap Repository Tracts were intended to provide a more uplifting form of balladry. Thousands of improving tracts were produced and freely disseminated but the very fact of their continued re-issue bore witness, not to their popularity, but to their limited impact. On the other hand, 'loyal' songs, particularly those written by Charles Dibdin, were better received, though this owed as much to the stirring tunes as to their sentiments.

Broadside ballads proved remarkably resilient and there may even have been a resurgence in their popularity in the early nineteenth century, but there were important changes in content, size and tone. By the 1820s ballads were more topical and novelty-oriented, shorter and even more respectable but, 
as an anonymous contributor to National Review noted as late as 1861 , they were 'adapted to and meet the wants and views' of the poor.' Further, as 'they are almost all written by persons of the class to whom they are addressed,' they provided 'one of those windows through which we may get a glimpse at the very large body of our fellow-citizens of whom we know so little. ${ }^{34}$ Particularly outside the great towns and cities, they retained a central position in popular cultural life. As late as the 1840s, the "chief circulation of the broad-sheet is in the country where the conservative instinct is strong,' and even twenty years later, 'the ballad-singer would pass slowly along the roadway by the front of the houses [in the village of Harpenden, Hertfordshire], singing some harrowing verses made up specially for the occasion. ${ }^{35}$ By then in town, 'the street ballad-singer is disappearing from amongst us,' and yet the street business was 'still enormous."

During the second quarter of the nineteenth newer forms for disseminating songs emerged. In particular, the songster - basically a pocket-sized anthology of popular song lyrics - came to play a more important role. Its origins are to be found in the eighteenth century and was a development of the more coherent chapbooks and other printed compilations of songs. Although part of the commercialization of leisure for the middle classes, the various Vauxhall Gardens songbooks illustrate the point well. Between 1745 to1848 there were at least 240 printed collections of songs, some containing as few as three or four songs, others more than $200 .{ }^{37}$ The midcentury publications were clearly aimed at a wealthy clientele. Lyric Harmony, a 31-page collection of eighteen 'entire new Ballads' written by Thomas Arne, was published in 1745 and sold for 6s. (£45 at current prices). The Wreath, published in 1755 was more ambitious, being 'a curious collection of above two hundred new songs, including those of the bottle, hunting, mirth, and jollity, with all those sung by the most eminent performers at Vauxhall, Ranlegh, Mary-bon, Cuypers-Garden, and all publick places of diversion. ${ }^{38}$ This formula continued to prove popular. The British Songster for 1834 ran to 434 pages and 'comprised a selection of the most admired plaintive and comic songs' but also contained 'all the new pieces which have been received with approbation and applause at the Theatre, 
Vauxhall Gardens, and other public places of amusement during the past season.' Other publications in similar vein included Jacob Beuler's Comic Songs to Popular Tunes, c.1820 and John Fairburn, junior, The Everlasting Songster: Being an extensive collection of One Thousand Naval, Love, Comic, Hunting, Bacchanalian, Sentimental, Scotch and Irish Songs, a compendium of about 1000 songs published in 1823 .

The Fairburn family was one of the most important printers of songsters. John Fairburn senior was producing songsters round the turn of the nineteenth century. ${ }^{39}$ In the mid-1820s his magnum opus appeared: the compendious Universal Songster, or Museum of Mirth. Initially published in eighty-four parts, each of 16 pages, and later as three 448-page volumes, it contained approximately 5000 songs. There were various categories of song - bacchanalian, sentimental, hunting, masonic and novelty as well as Irish, Scotch, Yorkshire and Provincial. The largest categories were comic songs (1111), amatory (909), sentimental (597) and bacchanalian $(358) .{ }^{40}$ In the introduction Fairburn made clear his intention 'to chronicle songs from the earliest period to the present day' based on his judgement of 'the pulse of public approbation.' The collection is something of a rag-bag. Volume 1, for example, contains 'God Save the King' and 'Rule Britannia' alongside songs from Shakespeare ('Who is Sylvia?'), Burns ('Macpherson's Lament'), and the Dibdins (Charles and Thomas) as well as 'Opossum Up a Gum Tree' and 'The Negro Drinking Song.' One wonders about the popularity of John Wilmot 's 'My Jealous Heart Would Break, Should We Have One Day Asunder' or (allegedly) Richard Coeur de Lion's 'No Wretched Captive of His Prison Speaks Unless With Pain,' albeit translated from the French. And it was expensive. In the introduction to volume 3 , Fairburn refers to 'rapid and extensive sale,' but this was not a cheap purchase. The first volume could be purchased in monthly parts for 1s (c. f4 at current prices), or weekly for $3 \mathrm{~d}$ each. in the 1820 s. The outlay for all eighty-four parts (or three volumes) would have been exorbitant, though by the 1840 s some retailers advertised the three volumes for $14 \mathrm{~s}$, a mere $£ 60$ at present prices. ${ }^{41}$

By the mid-nineteenth century smaller, often unbound, songsters sold for as little as $1 \mathrm{~d}$., bringing them, potentially at least, into the range of a large swathe of people. The impact 
of such printed music is difficult to determine with any precision. It would also be naïve to assume that printed music, still relatively expensive, provides an accurate guide to popular preference. ${ }^{42}$ Nonetheless, these were commercially produced works for which there was a market. More to the point, by increasing the available stock of songs, they enabled street singers and itinerant chanteurs to extend their repertoire with new, fashionable pieces and bring them to a wider audience. It is impossible to say how many of these songs were taken up, how quickly this happened and for how long they remained popular, but they had an impact well in excess of the number of songsters sold at the time.

\section{Some concluding observations}

Surveying the period from c.1770s to 1840 s, the most striking feature is the wide range of sources for songs, the dynamic inter-relationship between oral and printed traditions and the transmission of material from 'elite' culture to 'popular.' Equally important, was the growing topicality of broadsides in particular, which, combined with the sheer size and geographical spread of the trade, points to a popular culture that was not easily controlled, if at all, from above. This has important implications for the meanings of these songs, but what did people sing about? It is time to turn to consider the main topics and their treatment. 


\section{Endnotes}

1 Steve Roud argues it is 'a prime example of a field in which investigation at the micro level is still necessary before medium and higher-level theories will become feasible.' Introduction to D Atkinson \& S Roud, eds., Street Ballads in Nineteenth-century Britain, Ireland and North America, London, Routledge, 2016, p.2. Undoubtedly, in view of the flurry of recent and ongoing research, any generalizations need to be tentative.

2 V Gammon, Desire, Drink and Death in English Folk and Vernacular Song, 16001900, Aldershot, Ashgate, 2008, p.10

3 According to Clare 'I have heard him make a boast of it over his horn of ale, with his merry companions at the Blue bell public house ... that he could sing or recite above a hundred [ballads]; he had a tollerable [sic] good voice, \& was often calld upon to sing at those convivial bacchanalian merry makings.' Quoted in G Deacon, John Clare and the Folk Tradition, London, Sinclair Brown, 1983, p.22

4 W H Hudson, A Shepherd's Life, 1910, reprinted, London, Macdonald Futura, 1981, p.53

5 In Far from the Madding Crowd, Hardy, a knowledgeable observer of rural life, describes a shearing supper at which several songs are sung, including 'a poor plain ballet' [i.e. ballad] by the nerve-wracked Joseph Poorgrass (Chapter 23) and the singing and dancing at the harvest supper and wedding feast. (Chapter 36)

6 E. Robson ed., J Clare, Autobiographical Writings, Oxford University Press, 1986, p.55

7 P Quennell, ed., Mayhew's London, London, Spring Books, 1951, p.195

8 The Rush case was shocking, involving the double murder of father and son, the former being the Recorder of Norwich. The sensational evidence of Emily Sandford, Rush's mistress, determined the outcome of the case. Several thousand people, many coming by train to Norwich, saw Rush executed at Norwich Castle on 21 April 1849.

9 P Quennell, ed., London's Characters, London, Spring Books, 1951, p.30

10 Quennell, Mayhew's London, p.537. Unfortunately, the woman does not identify the streets in which she sang.

11 The first, based on Spencer's Faerie Queen, was a glee written in 1797; the second a song written by R Spofforth, c.1810 but I have been unable to identify with confidence the last song.

12 For poetry, J Barrell and John Bull, eds., English Pastoral Verse, Harmondsworth, Penguin, provides a good introduction. Landscape paintings of the eighteenth and nineteenth centuries are discussed in J Barrell, The Dark Side of the Landscape: the rural poor in English painting, 17301840, Cambridge University Press, 1983, A Bermingham, Landscape and Ideology: the English Rustic Tradition, 1740-1860, London, Thames \& Hudson, 1986, C. Payne, Toil and Plenty: Images of the Agricultural Landscape in England, 1780-1890, New Haven, Yale University Press, 1993 and C Wood, Paradise Lost: Paintings of English Country Life and Landscape, 1850-1914, London, Barrie \& Jenkins, 1988. 
13 Preface cited by P McDowell, 'The Manufacture and Lingua-facture of Ballad-Making: Broadside Ballads in Long Eighteenth-Century Ballad Discourse,' The Eighteenth Century, 47(2), 2006, pp.151-78 at p.164

14 F J Child, Preface,' The English and Scottish Ballads and quoted in McDowell 'Manufacture and Lingua-facture,' p.170

15 F J Child, 'Ballad Poetry' Johnson's Universal Cyclopaedia, 1, reprinted in Journal of Folklore Research, 31 (1994), pp.214-22 and cited by McDowell, 'Manufacture and Lingua-facture' p.171.

16 Worse, late-Victorian 'peasant' singers regaled the likes of the Reverend Sabine Baring Gould and Cecil Sharp with musical-hall ditties alongside time-honoured ballads.

17 See particularly, Atkinson \& Roud, Street Ballads but see also S Roud, Folk Song in England, London, Faber \& Faber, 2017.

18 Roud, Folk Song in England, discusses a dozen or so songs probably dating from before 1700 and a further 42 from the seventeenth century, half of which date from the latter part of the century. Folk Song, pp. $242 \& 271$.

19 W St Clair, The Reading Nation in the Romantic Period, Cambridge University Press, 2004 and D Atkinson, 'Was there really a 'Mass Extinction of Old Ballads' in the Romantic Period?' in Atkinson \& Roud, Street Ballads. St Clair emphasises the monopoly effect of the Stationers' Company and the 1715 Copyright Act, which ended in a crucial ruling in 1774. This ended perpetual copyright, unfroze the 'popular canon' and, according to St Clair, broadened the range of reading material, thereby reducing the demand for the 'ancient canon' of ballads.

20 Roud, Folk Song, pp. 235-8, the reference to Addison is at p.237. The Oxford Companion to English Literature refers to an early version dating from the fifteenth century https://www-oxfordreference-com.libaccess. hud.ac.uk/view/10.1093/acref/9780192806871.001.0001/acref9780192806871-e-1505

21 See the extract from a 1558 text associated with Richard Sheale 'minstrel' cited in Roud Folk Song, p.238.

22 The English Broadside Ballad Archive, University of California lists 53 songs to the tune 'Aim Not Too High' https://ebba.english.ucsb.edu/ search_combined $/ ? \mathrm{ft}=$ fish\&numkw $=52 \& \mathrm{p}=10$ Among the various songs were 'Sad news from Salisbury. Dreadful Frost and Snow,' 'The bloody-minded Husband,' 'A Caveat for Young Men,' 'A Looking-Glass for a Christian Family' and 'The Young Man's Repentance.' See also S Williams, 'To the Tune of Witchcraft:Witchcraft, Popular Song and the Seventeenth-Century English Broadside Ballad, 'Journal of Seventeenth-Century Music, 19 (1), 2013 published 2017 at https://sscm-jscm.org/jscm-issues/volume-19-no-1/to-the-tuneof-witchcraft/\#Ch3 'Lillibulero' was strongly associated with anti-Catholic sentiments - it 'sung a king out of three kingdom' according to Thomas Wharton and quoted approvingly by Lord Macaulay - but was also used for such songs as 'The City Cheat Discovered' and 'Faint Heart never won fair Lady; or, Good Advice to Batchelors How to Court and Obtain a Young Lass'

23 D Dugaw, "The Popular Marketing of "Old Ballads”: The Ballad Revival and Eighteenth-Century Antiquarianism Reconsidered.' Eighteenth-Century Studies, 21 (1), 1987, pp.71-90 
24 Exceptionally, collections of old ballads were still being printed in the late1830s. Dugaw, 'Popular Marketing' p. 89

25 Pills to Purge Melancholy is available at www.https://digital.nls.uk/specialcollections-of-printed-music/archive/91519824

26 C L Day, 'Pills to Purge Melancholy', Review of English Studies, 8 (30), 1932, pp.77-84. www.jstor.org/stables/508831

27 From volume 5 of Pills to Purge. See National Library of Scotland, Glen Collection of printed music https://digital.nls.uk/special-collections-ofprinted-music/archive/87909275

28 W Tinsley, Random Recollections, 1905 cited in L Shepard, The History of Street Literature, Newton Abbot, David \& Charles, 1973, p.99

29 Approximately 20 per cent of chapbooks in the bibliography of chapbooks housed at the Victoria \& Albert museum were printed in Newcastle. Thanks to Robert White, a nineteenth-century collector, there is substantial archive of local chapbooks. Wood, 'Newcastle Song Chapbooks' p.62

30 Wood, 'Newcastle Song Chapbooks' p.62. The figures in the table do not match statements elsewhere in the article. Wood later refers to 'more than 3,000 songs' (including repeats) of which he has identified '1,912 different songs' p.66

31 R. Palmer, 'Birmingham Broadsides and Oral Tradition' and Wood, 'Newcastle Song Chapbooks' in Atkinson \& Roud, Street Ballads. There are several articles, some more antiquarian than others, in the Musical Tradition Internet Magazine www.mustrad.org.uk of which the following are of particular interest: R Palmer, 'Birmingham Ballad Printers,' P Wood, 'Tyneside Song' and a series of pieces by R. Brown, 'Hurd of Shaftesbury,' Robert Walker of Norwich,' 'Porter - a Cotswold Printer,' Norfolk printings of murder and execution,' Besley of Exeter,' 'Some Printers in Cornwall,' 'Some Devon Printers' and 'More Merry Ballad-making.'

32 Quoted in G Deacon, John Clare and the Folk Tradition, pp.49-50. He also noted how 'the ballad from his pocket lost forlorn' was claimed as his own by 'the rude bird boy in the field alone.'

33 Among major digitalised collections, see the English Broadside Ballad Archive, University of California, Santa Barbara http://ebba.english.ucsb. edu/ and the Full English Digital Archive and the Roud Folk Song Index and Broadside Index at the Vaughan Williams Memorial Library at https:// www.vwml.org/

34 Anon, 'Street Ballads,' National Review, xiii, 1861, pp.397-419 at pp.399-400. Changes in tone are most clearly seen in bawdy songs and transgressive scaffold ballads, discussed later. There may have been changes in their collection rather than production A Bennett, 'Sources of popular song in early nineteenth-century Britain: problems and methods of research,' Popular Music, 2, 1982, pp.69-89.

35 E Grey, Cottage Life in a Hertfordshire Village, St. Albans, Fisher, Knight, 1935 cited in Palmer, The Sound of History, p.133

36 Anon, 'Street Ballads,' at pp. 399 and 400. See particularly Vic Gammons 'Introduction' to Desire, Drink and Death and Bates 'Morality for the Masses' especially chapter 7. Older chapbooks, such as 'Old Mother Shipton' that looked to preserve old customs and wisdom, while more modern ballads 
focussed on contemporary issues. SeeV E Neuburg, 'The Literature of the Streets' in H J Dyos \& M Wolff, eds., The Victorian City, Volume 1, London, Routledge \& Kegan Paul, 1976, pp. 191-209 at pp.206-7.

37 D Coke, Vauxhall Gardens 1661-1859 at www.vauxhallgardens.com which complements D Coke \& A Borg, Vauxhall Gardens: A History, Yale University Press, 2015

38 http://www.vauxhallgardens.com/vauxhall_gardens_songbooks_page.html

39 C.1810 he produced a six-volume Songster's Multum in Parvo, which sold in weekly parts at $2 \mathrm{~d}$., and during the 1810 s a number of $6 \mathrm{~d}$ numbers including a Naval Songster, containing 31 songs, and variously a Whimsical Songster, a Quizzical Songster, a Tickling Songster and a Larking Songster.

40 https://archive.org/details/universalsongst00unkngoog/ Most of the Irish, Yorkshire and Provincial songs were comic songs, many exploiting the 'yokel-up-in-town' motif. 'Zekiel Homespun's Trip to Town' is hardly a flattering picture of a Yorkshireman in London but 'Zedekiah the Jew' is positively hostile 'My customers - meet 'em/Mit pretty words - treat 'em/ Vat vhile I vas, cheat 'em/Is always my vay' etc., etc.

41 For example, Newcastle Courant, 25 December 1824 and Leeds Mercury, 14 March 1826. Manchester Courant, 14 October 1846. The bargain offer of $14 \mathrm{~s}$ for the three volumes compared with the published price of $\mathcal{K}^{1-4 \mathrm{~s}}$.

42 In contrast, the ease with which unsuccessful broadsides could be abandoned, suggests that repeat printings are an indicator of popularity. 